DOI https://doi.org/10.36059/978-966-397-235-0-18

Серватюк Л. В.,

orcid.org/0000-0003-2302-4729

кандидат юридичних наук, доцент, доцент кафедри загальноправових дисциплін Національної академії Служби безпеки України, м. Київ

\title{
ПОРУШЕННЯ ПРАВ ЛЮДИНИ В ДІЯЛЬНОСТІ ПРАВООХОРОННИХ ОРГАНІВ: ЗАПОБІГАННЯ ТА МОНІТОРИНГ
}

Анотація. $у$ статті проведено аналіз діяльності правоохоронних органів щодо забезпечення та захисту прав людини. Визначено спільні принципи й інструменти забезпечення дотримання прав людини та запобігання їх порушенню з боку посадових осіб правоохоронних органів. Узагальнено й упорядковано досвід проведення моніторингу прав людини в діяльності правоохоронних органів. Викладено концептуальні засади побудови та функціонування внутрішнього механізму моніторингу прав людини в правоохоронній діяльності. Окреслено основні механізми діяльності державних установ, національних $i$ міжнародних організацій громадянського суспільства 3 моніторингу прав людини в правоохоронній діяльності. Описано найбільш дієві методи (практики) зовнішнього моніторингу задля підвищення ефективності роботи національного превентивного механізму з виявлення та фіксації випадків катувань $i$ жорстокого поводження. Запропоновано певні пропозиції щодо покрашення рівня забезпечення міжнародних стандартів у сфері прав людини посадовими особами правоохоронних органів.

\section{Вступ}

Забезпечення законності, правопорядку, охорона прав, свобод і законних інтересів громадян - це предмет турботи держави, іï правоохоронних органів і посадових осіб цих органів.

Ступінь реалізації прав людини в державі значною мірою залежить від неухильного дотримання та виконання посадовими особами правоохоронних органів міжнародних договорів i законів у сфері забезпечення й захисту прав людини. Міжнародні 
Права людини в Україні та у зарубіжних країнах: традиції та новації

стандарти у сфері захисту прав людини мають бути безпосередньо спрямовані на регламентацію діяльності правоохоронних органів України.

Сьогодні основними критеріями оцінки діяльності правоохоронних органів держави $\epsilon$ ступінь захисту прав i законних інтересів громадян у їхній повсякденній діяльності, а також реалізація широкого спектру прав і свобод, передбачених Конституцією України та законами України.

Правоохоронним органам України притаманні такі спільні функції - запобігання злочинам (правопорушенням) і виявлення злочинів (правопорушень), підтримка й відновлення громадського порядку, надання своєчасної допомоги громадянам, у межах наданої законодавством компетенції. Такі ж функції $є$ спільними для більшості поліцейських структур як у Європі, так і в усьому світі.

Європейська конвенція про захист прав та основних свобод людини 1950 року визначає стандарти виконання своїх повноважень правоохоронними органами, в основу яких покладено принципи захисту й поваги прав людини, демократії та законності [1]. Це пов'язано з тим, що правовий статус цих органів передбачає виконання завдань, які можуть обмежувати права людини та їхні законні інтереси.

Наприклад, британські юристи вказують на нечітке визначення в праві самого поняття «злочину проти громадського порядку» як на одну з причин недостатньої ефективності його охорони й надмірного поліцейського насильства щодо осіб, які брали лише пасивну участь у групових безладдях, чи тих, хто став випадковим свідком. Закон повинен бути ясним, ефективним, який можна виконувати [2, с. 134].

Сьогодні значно частіше правоохоронні органи почали виявляти себе як виконавчо-репресивні органи. Ця тенденція універсальна й пов'язана із зростанням у всьому світі таких злочинних проявів, як тероризм, незаконний обіг наркотиків, нелегальна міграція, торгівля людьми, масові безладдя на грунті релігійного екстремізму та міжнаціональної ворожнечі, міжетнічні конфлікти тощо. Оскільки нині у світі відсутні достатньо ефективні засоби для запобігання таким правопорушенням, посилення репресивних функцій поліції буде зростати [3, с. 133]. 
Аналіз оперативно-службової діяльності правоохоронних органів свідчить, що сьогодні правова захищеність громадян у їхніх взаєминах між собою та іншими органами держави ще залишається недостатньою. Стандарти захисту прав людини в діяльності правоохоронних органів гарантуються лише Конституцією України. Деякі норми Конституції так і не набули сьогодні механізму реалізації в національному законодавстві, адже важливість урегулювання кримінального провадження, адміністративного процесу та провадження у справах про адміністративні правопорушення підтверджується тим, що саме в процесуальних механізмах стикаються інтереси суб'єктів основних прав (особи, що порушила закон) та інтересів суспільства (держави) загалом. Перед посадовими особами правоохоронних органів виникає потреба знаходити компроміс між суспільною необхідністю (притягнення до відповідальності винного) та захистом законних інтересів особи й визначення допустимості обмеження цих прав.

Отже, існує нагальна потреба в суттєвому поліпшенні діяльності правоохоронних органів у їхніх відносинах із громадянами. Для цього недостатньо чіткого на законодавчому рівні визначення їхніх повноважень і функцій (їх посадових осіб), необхідно створити механізм їх взаємодії з громадянами, при якому реалізація прав і свобод громадян була б звільнена від «бюрократичних» перешкод, а порушені права та свободи оперативно й ефективно поновлювалися.

\section{1. Діяльність правоохоронних органів щодо забезпечення й захисту прав людини}

За міжнародними договорами універсального та регіонального характеру у сфері прав людини, згода на обов'язковість яких надана Верховною Радою України, наша держава зобов'язується:

- $\quad$ створювати й підтримувати правове середовище, у якому можливе користування правами людини;

- уникати порушень прав людини державними (правоохоронними органами) та їх посадовими особами;

- виправляти ситуації, коли права людини було порушено, відновлювати порушене право та притягувати винних посадових осіб до відповідальності [1, с. 4-6]. 
Права людини в Україні та у зарубіжних країнах: традиції та новації

Для виконання зобов'язання щодо створення та підтримки правового середовища, у якому можливе користування правами людини, Україні необхідно постійно вносити зміни в чинні нормативно-правові акти, розробляти та впроваджувати нові. Як зазначалося вище, на рівні Конституції таке завдання виконане. Необхідно добиватися, щоб і закони, і підзаконні акти (накази, розпорядження, рішення різноманітних центральних і місцевих органів влади) органічно розвивали положення міжнародноправових актів і Конституції та не порушували їх. Будь-який державний службовець будь-якого рівня може та повинен указувати на невідповідності чи порушення, які закріплені в підзаконних нормативно-правових актах, і повідомляти про це по владній вертикалі для виправлення ситуації. Саме завдяки цьому можна уникнути ситуацій порушення прав людини.

Уникнення порушень прав людини означає не лише діяти відповідно до норм законодавства, а й постійно діяти відповідно до загального гуманістичного духу норм про повагу до прав людини й захист прав людини. Посадові особи правоохоронних органів з метою уникнення порушення прав людини можуть діяти як активно, так і пасивно. Пасивно - це повага прав людини, тобто утримання від дій, які порушують права людини. Активно - це захист прав людини, передбачає припинення дій інших осіб, які спрямовані на порушення прав людини.

Законодавець чітко визначив й основні принципи діяльності правоохоронних органів i ïх структурних підрозділів: законність, гуманізм, повага та дотримання прав людини, соціальна справедливість, взаємодія з населенням на засадах партнерства, відкритість, незалежність від впливу будьяких політичних, громадських об'єднань [7; 8; 9].

Для забезпечення дотримання правопорядку й запобігання вчиненню правопорушень з боку посадових осіб правоохоронних органів можуть слугувати такі інструменти:

- організація ефективної системи моніторингу виконання заходів забезпечення провадження, запобіжних заходів, слідчорозшукових дій адміністративних процедур з метою виявлення правопорушень або складних ситуацій, обставини яких можуть спонукати до порушення норм права;

- $\quad$ розробка етичних стандартів поводження співробітників правоохоронних органів, системи заохочення й застосування дисциплінарних заходів; 
- навчальна робота з персоналом на тему обізнаності у сфері законодавства про права людини та його дотримання в службовій діяльності;

- психологічна підготовка персоналу до стресових ситуацій, провокацій, роботи 3 вразливими категоріями осіб тощо;

- $\quad$ підготовка персоналу до роботи в умовах культурного та етнічного різноманіття;

- організація ефективної системи постійної звітності персоналу, оцінки його роботи і заохочень.

Аналіз відомчих нормативно-правових актів дає можливість зробити висновок, що в них доволі лаконічно та вичерпно сформовано образ працівника правоохоронних органів:

а) мати високі моральні якості, необхідну професійну підготовку;

б) бути дисциплінованими, пильними та чесними при виконанні службових обов'язків, діяти рішуче й наполегливо, стійко переносити всі труднощі, пов'язані зі службою, не шкодуючи своїх сил для виконання службових обов'язків;

в) виконувати свої завдання в точній відповідності до законів України;

г) поважати гідність особи і ставитися до неї гуманно, захищати права людини незалежно від іï соціального походження, расової та національної належності, громадянства, ставлення до релігії, статі, політичних та інших переконань;

д) не розголошувати відомості, що стосуються особистого життя людини, принижують її честь і гідність, якщо виконання обов'язків не вимагає іншого;

е) при зверненні до громадянина називати своє прізвище, звання та пред'являти на його вимогу службове посвідчення $[10 ; 11]$.

Дотримання цих принципів і вимог особливо актуальне в умовах законного застосування примусових заходів до особи під час виконання посадовими особами правоохоронних органів своїх повноважень, коли відбувається певне балансування на межі законного обмеження прав особи та можливого їx порушення 3 боку правоохоронців. Уникнути вказаного покликане чітке й неухильне виконання визначених законодавством процедур застосування примусових заходів обмеження прав особи, що містять процесуальні гарантії як для 
Права людини в Україні та у зарубіжних країнах: традиції та новації

особи, так і для самого правоохоронця щодо належної оцінки його роботи.

Таким чином, очевидно, що зобов'язання України щодо виконання принципу поваги до прав людини повинні виконуватися на всіх рівнях - від центрального апарату до окремого виконавця на місцях. Виконання зобов'язань має циклічний характер, і всі етапи взаємопов'язані.

\section{2. Внутрішній механізм моніторингу прав людини в правоохоронній діяльності}

Найефективнішим методом боротьби з правопорушеннями у сфері забезпечення прав людини є запобігання їм. Стратегія запобігання виникненню правопорушень має базуватися на аналізі інформації про правопорушення, що мали місце, а також про виникнення ситуацій, в умовах яких виникнення правопорушень має високу вірогідність[12, с.95]. Саме моніторингова діяльність покликана для збирання й аналізу такої інформації. Систему моніторингу можна умовно поділити на внутрішній і зовнішній моніторинг.

Моніторинг прав людини в правоохоронній діяльності термін, що описує активне збирання, перевірку й безпосереднє використання інформації для вирішення проблем з правами людини.

Моніторинг прав людини включає збирання інформації про інциденти, спостереження за подіями (виборами, судовими процесами, демонстраціями тощо), відвідання таких об’єктів, як місця утримання й табори біженців, проведення переговорів 3 органами влади для отримання інформації, виправних та інших наступних дій, а також заходи з оцінки, збору фактів та іншу роботу на місцях. Крім того, моніторинг має часовий вимір: він завжди триває досить довго [13].

Головне завдання моніторингу - не допустити порушення прав людини й запобігти їм. Для цього при моніторингу прав людини вивчають можливі причини порушень, пропонують рішення й заохочують підзвітність [14].

Моніторинг прав людини здійснюють державні органи, зокрема національні служби омбудсменів і національні інститути 3 прав людини, а також правозахисні та міжнародні організації. Моніторинг прав людини міжнародними та місцевими неурядовими організаціями - це додатковий механізм захисту 
Права людини в Україні та у зарубіжних країнах: традиції та новації

прав людини. Сприяння в здійсненні такої діяльності $\epsilon$ найпершим обов'язком держави. Розглянемо повноваження та сферу здійснення моніторингу прав людини основних з них.

Основою внутрішнього моніторингу в органах державної влади $\epsilon$ передусім система звітності персоналу щодо всіх процесуальних дій, які вчиняють посадові особи. Кожна процесуальна дія має бути зафіксована в процесуальних документах (протоколах), які, у свою чергу, мають реєструватися у відповідних журналах. Ураховуючи специфіку діяльності силових правозахисних органів, особливої уваги потребує документування всіх випадків застосування сили, спеціальних заходів, зброї, здійснення будь-яких заходів дисциплінарного характеру щодо правопорушника. Протоколи й журнали мають проходити регулярну перевірку з боку безпосереднього та вищого керівництва.

Не варто обмежуватися самостійним збиранням інформації. Не менш корисним джерелом інформації можуть стати самі й громадяни, що перебувають у процесуальних процедурах або залежно від дій посадових осіб правоохоронних органів. Для збирання інформації щодо випадків порушення прав використовуються опитування, співбесіди, діє система подання скарг.

Так, наприклад, Державна прикордонна служба сприяє здійсненню права мігранта подавати скарги, що закріплено в низці внутрішніх нормативних актів ДПСУ. Зокрема, в Інструкції «Про порядок тримання ...» іноземцю на його прохання мають надаватись ручка й папір для написання скарги, а у випадку написання скарги до прокурора, Уповноваженого Верховної Ради України з прав людини чи Європейського суду з прав людини також надається конверт, який заклеюється. За бажанням мігранта для написання скарги його може бути відведено до окремої кімнати. Усі отримані скарги для вчасного вирішення проблеми, що $\epsilon$ предметом скарги, і для ефективного аналізу чинного стану правопорядку мають розглядатися в якомога коротший термін [15].

Розгляд письмових скарг $є$ ефективним, але недостатнім заходом для оцінки реального стану правопорядку. Для всеохоплюючого аналізу ситуації відповідні підрозділи правоохоронних органів мають самостійно проявляти ініціативу для отримання інформації через проведення письмових 
Права людини в Україні та у зарубіжних країнах: традиції та новації

опитувань i регулярних усних співбесід із затриманими (ув'язненими) особами. Письмові опитування можуть допомогти зібрати статистичну інформацію про стан дотримання правопорядку, а неформальні усні співбесіди можуть стати джерелом корисних рекомендацій щодо покращення стандартів (умов) їх утримання.

У деяких пунктах тимчасового тримання, а також у закладах тримання (перебування) іноземців (осіб без громадянства) Державної міграційної служби України, встановлено скриньки для подання анонімних скарг, хоча, згідно з українським законодавством, анонімні скарги не можуть бути підставою для порушення провадження (службового розслідування), вони можуть бути ефективним методом аналізу реального стану забезпечення прав людини в закладі тримання.

Дієвим механізмом внутрішнього моніторингу $€$ й організаційна структура правоохоронних органів. Для неї характерною ознакою $\epsilon$ багаторівнева підзвітність, тобто перевірки щодо кожної структурної одиниці органу можуть проводитися не тільки органом, якому він безпосередньо підпорядкований, а й усіма іншими органами, які $\epsilon$ вищими за ієрархією. Це дає широкі можливості для здійснення моніторингу у сфері дотримання прав людини та може впливати на належність і прозорість діяльності посадових осіб.

Сьогодні в системі Міністерства внутрішніх справ створено окремі органи внутрішнього моніторингу дотримання прав людини: Управління моніторингу дотримання прав людини та Громадська рада при Міністерстві внутрішніх справ України.

Управління моніторингу дотримання прав людини здійснює моніторинг і контроль дотримання прав людини в діяльності MBC і за дорученням міністра центральних органів виконавчої влади, діяльність яких спрямовується й координується Кабінетом Міністрів України через міністра внутрішніх справ України. Завданнями Управління є:

1. Здійснення в межах компетенції контролю за дотриманням прав людини в діяльності МВС і центральних органів виконавчої влади.

2. Моніторинг, вивчення й аналіз проблемних питань, пов'язаних із порушенням прав людини в діяльності MBC і центральних органів виконавчої влади, надання керівництву $\mathrm{MBC}$ пропозицій щодо їх розв'язання. 
3. Надання керівництву та державному секретарю Міністерства внутрішніх справ України пропозицій щодо вдосконалення нормативно-правових актів МBC стосовно забезпечення прав і свобод людини відповідно до вимог міжнародних і національних нормативних актів із забезпечення прав людини та рішень Європейського суду з прав людини.

4. Забезпечення взаємодії MBC із центральними органами виконавчої влади й іншими органами державної виконавчої влади, міжнародними та національними неурядовими організаціями із забезпечення прав людини [16].

Громадська рада при Міністерстві внутрішніх справ України - тимчасовий консультативно-дорадчий орган, утворений для сприяння участі громадськості у формуванні та реалізації державної політики у сфері забезпечення охорони прав і свобод людини, інтересів суспільства й держави, протидії злочинності, підтримання публічної безпеки та порядку, а також надання поліцейських послуг; захисту державного кордону й охорони суверенних прав України в її виключній (морській) економічній зоні; цивільного захисту, захисту населення й територій від надзвичайних ситуацій i запобігання їx виникненню, ліквідації надзвичайних ситуації, рятувальної справи, гасіння пожеж, пожежної та техногенної безпеки, діяльності аварійно рятувальних служб, а також гідрометеорологічної діяльності; міграції, у тому числі протидії нелегальній міграції, громадянства, реєстрації фізичних осіб, біженців та інших визначених законодавством категорій мігрантів.

Основними завданнями Громадської ради є:

1) сприяння реалізації громадянами конституційного права на участь в управлінні державними справами;

2) сприяння врахуванню MBC громадської думки під час формування та реалізації державної політики у сферах, що належать до компетенції MBC;

3) сприяння залученню представників заінтересованих сторін до проведення консультацій 3 громадськістю та моніторингу результатів формування й реалізації державної політики у сферах, що належать до компетенції MBC;

4) проведення відповідно до законодавства громадського моніторингу діяльності МВС; 
Права людини в Україні та у зарубіжних країнах: традиції та новації

5) здійснення підготовки експертних пропозицій, висновків, аналітичних матеріалів 3 питань формування й реалізації державної політики у сферах, що належать до компетенції MBC [17].

Отже, можна зробити висновок, що внутрішній механізм моніторингу прав людини в правоохоронній діяльності налагоджений. Один із основних обов'язків посадових осіб правоохоронних органів - дотримання та покращення вже чинних стандартів кримінальних та адміністративних процедур: усі затримання мають бути своєчасно оформлені та здійснені в чіткій відповідності до закону; усі затримані мають бути своєчасно поінформовані про їхні права й отримати можливість повідомити третю сторону про факт затримання, отримати можливість спілкування з адвокатом до першого допиту та безперешкодний доступ до лікаря за власним вибором.

\section{3. Зовнішній механізм моніторингу прав людини в правоохоронній діяльності}

Зовнішній моніторинг прав людини в правоохоронній діяльності здійснюють державні органи, зокрема національні служби омбудсменів і національні інститути з прав людини, а також правозахисні та міжнародні організації. Моніторинг прав людини міжнародними й місцевими неурядовими організаціями - це додатковий механізм захисту прав людини. Сприяння в здійсненні такої діяльності $є$ найпершим обов'язком держави. Розглянемо повноваження та сферу здійснення моніторингу прав людини основних із них.

Вагоме місце в системі державного контролю за дотриманням прав людини в більшості розвинених країн посідає інститут омбудсмана. 3 давньоскандинавської мови «омбудсман» перекладається як «представник». Уперше посаду омбудсмана запроваджено у Швеції в 1809 р., згодом у 1919 р. інститут омбудсмана запроваджено у Фінляндії. Подальшого розповсюдження ця посада набула лише після II Світової війни.

В Україні посада омбудсмана офіційно називається Уповноважений Верховної Ради Украӥни з прав людини. Вона заснована в 1998 р. Законом України «Про Уповноваженого Верховної Ради України з прав людини». Метою контрольної діяльності омбудсмана в Україні Закон визначає таке: 
Права людини в Україні та у зарубіжних країнах: традиції та новації

1) захист прав i свобод людини та громадянина, проголошених Конституцією України, законами України й міжнародними договорами України;

2) додержання й повага до прав і свобод людини та громадянина органами державної влади, органами місцевого самоврядування та їх посадовими й службовими особами;

3) запобігання порушенням прав і свобод людини та громадянина або сприяння їх поновленню;

4) сприяння приведенню законодавства України про права i свободи людини та громадянина у відповідність до Конституції України, міжнародних стандартів у цій галузі;

5) поліпшення й подальший розвиток міжнародного співробітництва в галузі захисту прав і свобод людини та громадянина;

6) запобігання будь-яким формам дискримінації щодо реалізації людиною своїх прав і свобод;

7) сприяння правовій інформованості населення та захист конфіденційної інформації про особу [18].

У 2011 p. Президент України запровадив посаду Уповноваженого Президента України з прав дитини. Метою запровадження нової посади є здійснення Президентом України конституційних повноважень щодо забезпечення й додержання конституційних прав дитини, виконання Україною міжнародних зобов'язань у цій сфері. Основними завданнями Уповноваженого з прав дитини є:

1) постійний моніторинг додержання в Україні конституційних прав дитини, виконання Україною міжнародних зобов'язань у цій сфері та внесення в установленому порядку Президентові України пропозицій щодо припинення повторення й запобігання повторенню порушень прав і законних інтересів дитини;

2) унесення Президентові України пропозицій щодо підготовки проектів законів, актів Президента України з питань прав і законних інтересів дитини;

3) здійснення заходів, спрямованих на інформування населення про права та законні інтереси дитини[19].

В Україні також діють і специфічні повноваження Президента України, яких не існує в інших державах Європи чи світу. Наприклад, 25 квітня 2019 р. запроваджено Уповноваженого із захисту державної мови (мовного омбудсмена). Мета 
Права людини в Україні та у зарубіжних країнах: традиції та новації

діяльності - сприяння функціонуванню української мови як державної у сферах суспільного життя, визначених Законом України «Про забезпечення функціонування української мови як державної» [20].

Іншим є Уповноважений Президента України з питань контролю за діяльністю СБУ - відповідальний державний службовець, який здійснює постійний контроль за діяльністю Служби безпеки України. Основні повноваження:

- здійснює контроль за додержанням органами й підрозділами Служби безпеки України конституційних прав громадян і законодавства в оперативно-розшуковій діяльності та діяльності у сфері охорони державної таємниці;

- вивчає положення, накази, розпорядження, інструкції й указівки Служби безпеки України 3 метою визначення їх відповідності Конституції та законам України, в установленому порядку реєструє ці нормативно-правові акти й уживає заходів щодо включення їх до Єдиного державного реєстру нормативноправових актів;

- $\quad$ розглядає за дорученням Президента України звернення громадян щодо порушення їхніх конституційних прав і свобод, інших порушень у діяльності Служби безпеки України, а також зауваження та пропозиції щодо її діяльності;

- розглядає інформацію 3 основних питань діяльності Служби безпеки України, випадки порушення законодавства та вносить за результатами розгляду в установленому порядку відповідні пропозиції;

- розробляє та подає Президентові України пропозиції щодо здійснення заходів, спрямованих на забезпечення додержання конституційних прав громадян i вимог законодавства в оперативно-розшуковій, контррозвідувальній діяльності й діяльності у сфері охорони державної таємниці органів і підрозділів Служби безпеки України [21].

Комітет оон з питань недопущення катувань контролюючий орган, який здійснює нагляд за виконанням Конвенції проти катувань та інших жорстоких, нелюдських або таких, принижують гідність, видів поводження й покарання. Перша сесія Комітету відбулася у квітні 1988 р. в м. Женеві. Сьогодні Комітет проводить у Відділенні ООН у Женеві двічі на рік чотиритижневі сесії. Передбачена також можливість 
скликання спеціальних сесій за ініціативою більшості членів Комітету або в разі звернення держави-учасника Конвенції.

Україна повністю визнає на своїй території дію статті 22 Конвенції проти катувань та інших жорстоких, нелюдських або таких, що принижують гідність, видів поводження й покарання 1984 р. щодо визнання компетенції Комітету проти катувань отримувати та розглядати повідомлення осіб, які перебувають під юрисдикцією держави-учасниці та які стверджують, що вони $\epsilon$ жертвами порушення державою-учасницею положень Конвенції, чи повідомлення такого роду, що надходитимуть від їхнього імені [22].

Комітет має компетенцію в отриманні інформації й проведенні розслідування, які стосуються заяв про систематичне застосування катувань у державах-учасницях. Може пропонувати спеціалізованим Установам ООН, міжурядовим організаціям 3 консультативним статусом при ЕКОСОР подавати йому інформацію, документацію та письмові заяви, які стосуються діяльності, що він проводить відповідно до Конвенції. Представляє державам-учасникам і ГА ООН щорічну доповідь про свою роботу.

Держави-учасниці подають Комітету через Генерального секретаря ООН доповіді про вжиті ними заходи щодо здійснення своїх зобов'язань відповідно до Конвенції. Перша доповідь подається протягом одного року після набуття чинності Конвенції для відповідної держави. У подальшому подаються раз на чотири роки додаткові доповіді про будь-які нові вжиті заходи, а також інші доповіді та відомості за проханням Комітету.

Приклад із практики. 6 листопада 2014 р. - Комітет ООН проти катувань сьогодні завершив розгляд шостої періодичної доповіді України щодо виконання положень Конвенції проти катувань та інших жорстоких, нелюдських або таких, що принижують гідність, видів поводження й покарання.

Представляючи доповідь, Наталія Севастьянова, Урядовий уповноважений у справах Європейського суду з прав людини, Міністерства юстиції України, зазначила, що Кримінальнопроцесуальний кодекс 2012 року, у якому передбачаються рівне право на захист, гарантія права на захист і чіткі критерії прийнятності доказів, зруйнував парадигму покарання. У березні 2014 р. уряд ухвалив програму діяльності Кабінету Міністрів, спрямовану на забезпечення захисту прав людини й діяльності 
Права людини в Україні та у зарубіжних країнах: традиції та новації

інституту безкоштовної юридичної допомоги, запровадженого у 2011 р. Україна вживає всіх можливих заходів для забезпечення основних прав і свобод на територіях, окупованих і анексованих Росією, а також проводить розслідування актів жорстокого поводження, катувань, викрадення або смерті [23].

Іншою важливою функцією Комітету $\epsilon$ проведення конфіденційних розслідуванні за обгрунтованими даними про систематичне застосування катувань на території державиучасниці Конвенції. Якщо Комітет одержує вірогідну інформацію, яка, на його думку, містить цілком обгрунтовані дані про систематичне застосування катувань на території якої-небудь держави-учасниці, то він пропонує цій державі співробітничати в розгляді цієї інформації, із цією метою подати свої зауваження щодо цієї інформації. Комітет може, якщо він уважає за доцільне, призначити одного або кількох своїх членів для проведення конфіденційного розслідування й термінового подання Комітету відповідної доповіді. По закінченні розслідування Комітет направляє державі його результати, а також власні зауваження та пропозиції. Після консультацій із зацікавленим державою Комітет може прийняти рішення про включення короткого звіту про результати роботи в щорічну доповідь. Тільки в такому випадку діяльність Комітету оприлюднюється, в інших випадках уся діяльність і документи є конфіденційними.

Відповідно до статті 21, Комітет може розглядати повідомлення держав-учасниць Конвенції про те, що інші держави-учасниці не виконують своїх зобов'язань за нею. Умовою запуску цієї процедури $\epsilon$ визнання відповідної компетенції Комітету обома зацікавленими державами.

Комітет розглядає питання, передане йому, лише після того, як він упевниться, що в цьому разі всі доступні внутрішні заходи були вжиті й вичерпані відповідно до загальновизнаних принципів міжнародного права. Це правило не діє в тих випадках, коли застосування цих заходів невиправдано затягується й навряд чи надасть ефективну допомогу особі, яка $є$ жертвою порушення цієї Конвенції. Розгляд повідомлень Комітет проводить на закритих засіданнях. Комітет також надає послуги цим державам 3 метою дружнього вирішення спору на підставі поваги до зобов'язань, передбачених у цій Конвенції, із цією метою може за необхідності заснувати спеціальну погоджувальну комісію. Відповідні держави-учасниці мають 
Права людини в Україні та у зарубіжних країнах: традиції та новації

право бути представленими при розгляді питання в Комітеті й робити усні чи письмові заяви. На практиці ця процедура жодного разу не задіяна.

Стаття 22 Конвенції передбачає повноваження Комітету розглядати індивідуальні повідомлення від фізичних осіб про порушення державою-учасником її положень. Відповідна стаття Конвенції має факультативний характер: держави-учасники можуть у будь-який час заявити про визнання компетенції Комітету отримувати й розглядати повідомлення осіб, які знаходяться під його юрисдикцією, котрі стверджують, що вони $\epsilon$ жертвами порушення державою-учасницею положень Конвенції, або повідомлення такого роду, що надходять від їхнього імені.

Приклад із практики. На розгляд Комітету групою українських правозахисних організацій подано альтернативний звіт щодо дотримання Росією Конвенції ООН проти катувань та інших жорстоких, нелюдських або таких, що принижують гідність, видів поводження й покарання на території окупованого нею Криму у 2014-2018 рр., співавторами якого виступили Українська Гельсінська спілка з прав людини, Регіональний центр прав людини, Медійна ініціатива за права людини та окремі експерти. Комітет урахував майже всі висновки й рекомендації українських правозахисників і закликав Росію припинити практику катувань у Криму та м. Севастополі, забезпечити судове переслідування й покарання винних осіб і надання відшкодування жертвам, а також забезпечити безперешкодний доступ до півострову для міжнародних механізмів моніторингу прав людини [24].

Комітет не приймає до розгляду повідомлення, що $\epsilon$ анонімним, на його думку, або результатом зловживання правом на подання таких повідомлень, або несумісне з положеннями цієї Конвенції. Про надходження й прийняття повідомлення Комітет доводить до відома зацікавленої держави. Протягом шести місяців держава, що одержала повідомлення, подає до Комітету письмові пояснення або заяви, що уточнюють питання й будь-які заходи, які могли бути прийняті цією державою.

Комітет не розглядає жодних повідомлень від будь-якої особи, поки не переконається в такому:

а) це саме питання не розглядалося й не розглядається за якою-небудь процедурою міжнародного розслідування чи врегулювання; 
Права людини в Україні та у зарубіжних країнах: традиції та новації

b) ця особа вичерпала всі наявні внутрішні заходи правового захисту;

Це правило не діє в тих випадках, коли застосування цих заходів невиправдано затягує допомогу й навряд чи надасть ефективну допомогу особі, яка $\epsilon$ жертвою порушення цієї Конвенції [25].

Комітет розглядає одержані повідомлення з урахуванням i розглядом усієї інформації, представленої йому особоюзаявником або від їі імені та відповідною державоюпорушницею. Розгляд проводиться в закритому форматі. За його підсумками Комітет надсилає свої думки обом сторонам.

У світлі всієї інформації, отриманої від окремої особи чи від відповідної держави, Комітет розглядає повідомлення й формує стосовно них свої думки. Члени комітету можуть висловлювати свої окремі думки. Процедура розгляду завершується 3 передачею остаточних думок авторові повідомлення та відповідній державі учасниці, якій Комітет також пропонує інформувати його про заходи, які вона вживає відповідно до цих думок. Резюме розгляду повідомлень, заяв відповідних державучасниць і власних думок включається комітетом у його щорічну доповідь [26].

Приклад із практики. Комітет проти катувань розглянув шостий періодичний звіт РФ (CAT/C/RUS/6) під час 1658-ї та 1661-ї сесій, що відбулися 25 та 26 липня 2018 р. (див. CAT/C/SR.1658 та CAT/C/SR.1661), і прийняв ці Заключні зауваження під час 1676-ї та 1677-ї сесій, що відбулися 8 серпня $2018 \mathrm{p}$.

Не надаючи оцінку правовому статусу Криму в рамках міжнародного права та підкреслюючи фундаментальне значення принципу територіальної цілісності всіх країн-членів Організації Об'єднаних Націй, Комітет зазначає, що Крим знаходиться під ефективним контролем Російської Федерації та що Російська Федерація зобов'язана забезпечувати виконання положень Конвенції в Криму. Комітет висловлює своє занепокоєння щодо:

(a) постійних повідомлень про серйозні порушення прав людини, включаючи викрадення, свавільні арешти, насильницькі зникнення, катування, жорстоке поводження та позасудові страти, зокрема щодо кримських татар, проукраїнських активістів та осіб, пов'язаних із Меджлісом, з боку представників Федеральної служби безпеки та кримської самооборони; 
(b) інформації, що з 2014 р. влада регулярно застосовує тортури з метою отримання фальшивих зізнань для політично вмотивованих переслідувань;

(c) інформації про те, що, незважаючи на 106 заяв про ймовірне застосування державними службовцями катувань у період з лютого 2014 по червень 2018 рр., не проведено ефективного розслідування жодного з випадків;

(d) жахливих умов ув'язнення, зокрема недостатнього доступу до медичної допомоги, що спричинило численні смерті в місцях позбавлення волі;

(е) обмеженого доступу до місць позбавлення волі для представників незалежних механізмів моніторингу, громадянського суспільства й адвокатів затриманих;

(f) відмови надати доступ до Криму міжнародним правозахисним механізмам, зокрема Моніторинговій місії ООН 3 прав людини в Україні (статті 2, 4, 11, 12 і 16) [24].

Як i багато інших договірних органів, Комітет видає зауваження чи пропозиції загального характеру 3 питань роз'яснення або застосування положень Конвенції. Іншою формою вираження думки Комітету $\epsilon$ публічні заяви 3 актуальних питань, що мають відношення до втілення в життя положень Конвенції. Ці заяви робляться як власне Комітетом, так і спільно з іншими органами ООН або договірними органами.

Підкомітет із запобігання катуванням та іншим жорстоким, нелюдським або таким, що принижують гідність, видів поводження й покарання Комітету проти катувань заснований відповідно до Факультативного протоколу до Конвенції проти катувань та інших жорстоких, нелюдських або таких, що принижують гідність, видів поводження й покарання, почав свою роботу у 2007 p.

Основним завданням Підкомітету з недопущення покарань $\epsilon$ регулярне відвідування місць позбавлення волі на території держав-учасниць і надання рекомендацій їм щодо захисту позбавлених волі осіб від катувань та інших жорстоких, нелюдських або таких, що принижують гідність, видів поводження й покарання [27]. Підкомітет не розглядає періодичних докладів, не приймає індивідуальних повідомлень і не видає зауважень загального порядку.

Приклад із практики. Підкомітет повторно рекомендує привести положення Кримінального кодексу України, які 
Права людини в Україні та у зарубіжних країнах: традиції та новації

стосуються визначення катування, у повну відповідність до статті 1 Конвенції проти катувань.

Члени Підкомітету ООН 3 недопущення катувань також рекомендували, щоб з моменту взяття під варту всі затримані отримували повну інформацію про причини їх затримання або тримання під вартою та про їхні права, щоб вони мали можливість поінформувати рідних про місце й час затримання, щоб у момент узяття під варту затримані проходили ретельний медичний огляд, а доступ до них адвоката надавався з моменту затримання і протягом усього періоду тримання під вартою.

Підкомітет також рекомендував переглянути й реформувати систему обліку затриманих, «щоб облікові записи завжди були вичерпними, точними й постійно оновлювалися», поліпшити умови утримання в камерах, включаючи водопостачання та дотримання санітарних вимог, а також вирішити проблему відсутності бодай якоїсь фізичної діяльності осіб, що відбувають довічне ув'язнення [28].

Форма роботи Підкомітету сесії, які проводяться не рідше одного разу на рік, причому одна з них збігається із сесією Комітету проти катувань. Організаційно-технічне забезпечення роботи Комітету здійснює Секретаріат ООН.

Підкомітет направляє свої рекомендації та зауваження в конфіденційному порядку державі-учасниці й за необхідності національного механізму із запобігання катуванням (превентивного механізму). Крім того, він консультує національні превентивні механізми та надає державам сприяння в їх створенні.

Підкомітет співпрацює 3 відповідними органами й механізмами $\mathrm{OOH}$, а також із міжнародними, регіональними та національними установами або організаціями, що діють в інтересах посилення захисту всіх осіб від катувань та інших жорстоких, нелюдських або таких, що принижують гідність, видів поводження й покарання.

Європейський комітет з питань запобігання катуванням (далі - КЗК) - створений відповідно до Європейської конвенції про запобігання катуванням чи нелюдському або такому, що принижує гідність, поводженню й покаранню, яка підписана Страсбурзі 26 листопада 1987 р. й набула юридичної сили в 1989 p. 
Відповідно до статті 1 Конвенції, КЗК здійснює свої повноваження шляхом проведення інспекцій, перевірок щодо поводження з позбавленими волі особами з метою посилення а разі необхідності захисту таких осіб від катувань чи нелюдського або такого, що принижує їхню гідність, поводження чи покарання. До таких місць відносять в'язниці, заклади для утримання неповнолітніх, поліцейські дільниці, центри для утримання порушників міграційного законодавства, психіатричні лікарні, соціальні заклади тощо.

Окрім того, КЗК оцінює відповідність своїм стандартам в'язничної політики держави. Його зауваження можуть стосуватися, наприклад, питань перенаповненості пенітенціарних установ чи проблем національного кримінального виконавчого законодавства [29].

Кожна Сторона дозволяє інспектувати, відповідно до Конвенції, будь-яке місце, яке знаходиться під її юрисдикцією та в якому утримуються особи, позбавлені волі органом державної влади. Виконуючи цю Конвенцію, Комітет і компетентні національні органи відповідної Сторони співпрацюють між собою [30].

Делегації КЗК здійснюють інспекції періодично, як правило, один раз на чотири роки. За необхідності може організовувати додаткові позачергові інспекції. КЗК перед направленням своєї делегації повідомляє уряд держави про свій намір здійснити інспекцію. Після такого повідомлення делегація має необмежений доступ до місць позбавлення волі в будь-який час i право вільно пересуватися всередині таких установ. Вони мають право конфіденційно спілкуватися з позбавленими волі особами та вільно спілкуватися з будь-якою особою, яка, на їхню думку, може надати необхідну інформацію. Також можуть здійснювати фото-, відеофіксацію фактів, які вважають за належне до своїх завдань. Усі зібрані відомості є конфіденційними.

\section{3 метою сприяння КЗК у виконанні його завдання держава забезпечує:}

а) доступ на свою територію і право подорожування по ній без будь-якого обмеження;

b) повну інформацію про місця, де тримаються особи, позбавлені волі; 
c) необмежений доступ до будь-якого місця, де знаходяться особи, позбавлені волі, включаючи право відвідування таких місць без будь-якого обмеження;

d) іншу наявну інформацію, яка необхідна КЗК для виконання ним свого завдання, ураховуючи норми чинного національного законодавства та професійної етики.

У виняткових випадках компетентні органи держави можуть заявляти делегації КЗК заперечення щодо здійснення інспекції в термін або до місця, що запропоновані КЗК. Такі заперечення можуть мотивуватися тільки інтересами національної оборони, державної безпеки, серйозними заворушеннями в місцях знаходження осіб, позбавлених волі, станом здоров'я відповідної особи або проведенням термінового допиту у зв'язку з тяжким правопорушенням.

У разі наявності таких заперечень КЗК і відповідна держава невідкладно проводять консультації з метою з'ясування ситуації та досягнення згоди про вжиття заходів, які дали б змогу делегації Комітету швидко виконати свої функції.

Інспекції здійснюються делегаціями, до складу яких, як правило, входять кілька членів КЗК, котрих супроводжують працівники секретаріату Комітету й за необхідності експерти та перекладачі.

Після кожної інспекції КЗК складає докладну доповідь про факти, які встановлені під час інспекції, з урахуванням будь-яких міркувань, що можуть бути висловлені відповідною державою. Ця доповідь містить будь-які необхідні, на його думку, рекомендації, коментарі та запити про надання інформації. Комітет може проводити з відповідною державою консультації 3 метою внесення в разі необхідності пропозицій про поліпшення захисту позбавлених волі осіб.

Доповіді не можуть бути опубліковані без відповідного дозволу національного уряду. Якщо ж держава відмовляється від співпраці або відмовляється поліпшити ситуацію у світлі рекомендацій Комітету, Комітет може більшістю у дві третини голосів своїх членів прийняти рішення про оприлюднення заяви із цього приводу.

Приклад із практики. Під час сьомого періодичного візиту до України (8-21 грудня 2017 р.) Комітет вивчав умови тримання в правоохоронних органах (Національна поліція, Державна 
Права людини в Україні та у зарубіжних країнах: традиції та новації

прикордонна служба, Служба безпеки), пенітенціарній системі, психіатричних лікарнях і психоневрологічних інтернатах.

Комітет відзначив, що отримав багато скарг на надмірне застосування сили під час затримання поліцією, а також звинувачення у фізичному насильстві під контролем поліції (в основному опитані вказували на удари кулаками та дубинками, штурхани, а також на тісні наручники). Такі звинувачення частіше лунали в Києві, ніж у регіонах. У столиці також частіше скаржилися на жорстоке поводження 3 боку оперативних співробітників для отримання від затриманих інформації.

Також Комітет указав на практику неофіційних затримань i неофіційних допитів. Делегація звернула увагу на відсутність надання системної медичної допомоги затриманим i на відсутність конфіденційного спілкування з лікарем. Комітет звернув увагу на проблеми з отриманням якісної безкоштовної правової допомоги.

Комітет також звернув увагу на прогалини в розслідуванні катувань, що виникли після появи Державного бюро розслідування, коли прокуратура втратила повноваження розслідувати злочини, а бюро ще не набуло спроможності це робити. У будь-якому разі слідчі бюро повинні мати необхідні знання, щоб розслідувати злочини катувань, наголошено у звіті [31].

КЗК не є судовим органом. Його повноваження та діяльність являє собою превентивний механізм не судового характеру для захисту й забезпечення прав осіб, позбавлених волі, і їх захист від катувань та інших форм неналежного поводження. Тим самим він доповнює діяльність Європейського суду з прав людини. Європейський суд з прав людини користується доповідями КЗК для цілей підкріплення своїх позицій і навіть для підтвердження стверджуваних фактичних обставин справи окремих засуджених, якщо вони звернулися до Суду, а КЗК відвідував установи їхнього тримання в минулому.

Моніторинг прав у сфері притулку від імені ООН здійснює Управління Верховного комісара оОН у справах біженців. УВКБ ООН слідкує за дотриманням порядку процедури надання притулку, прав осіб, що звернулися до країни-члена за притулком, а також прав осіб, що отримали статус біженця.

Приклад із практики. Громадськість або міжнародні правозахисні організації не мають безпосередньої можливості здійснювати моніторинг порушення прав людини на державному 
кордоні в міжнародному аеропорті «Бориспіль», який є головним місцем в'їзду іноземців до України. Якщо шукач притулку до паспортного контролю зміг повідомити про себе Управління Верховного Комісару ООН у справах біженців (УВКБ ООН) або його виконавчого партнера, лише у випадку надання дозволу першим заступником голови ДПСУ така особа зможе отримати доступ до процедури міжнародного захисту й безкоштовної правової допомоги. I навіть у тих украй рідких випадках надання дозволів на побачення 3 de facto затриманими шукачами притулку часто представники УВКБ $\mathrm{OOH}$ i його виконавчих партнерів не встигають фізично дістатися місця затримання, як ДПкС уже примусово повертає шукача притулку до його країни походження, а свої дії пояснює тим, що повернута особа не заявляла про бажання отримати міжнародний захист [32].

Представництва Міжнародної організації з питань міграції (далі - МОМ) у країнах-членах здійснюють моніторинг у рамках різноманітних проектів, що ними виконуються. Представництво МОМ в Україні 32009 р. здійснює моніторинг прав осіб, затриманих у пунктах тримання, під управлінням Державної міграційної служби України й деяких пунктів тримання Державної прикордонної служби України. Механізм моніторингу МОМ включає в себе:

- присутність співробітників партнерських неурядових організацій (юристів, перекладачів, психологів тощо) в пунктах тримання;

- складання партнерських неурядових щомісячних звітів щодо стану дотримання прав затриманих і загальних тенденцій у пункті тримання;

- складання (на базі звітів неурядових організацій) зведених щомісячних статистичних і щоквартальних аналітичних звітів про стан справ у пунктах тримання й загальні тенденції у сфері незаконної міграції в Україні. Звіти розповсюджуються серед органів державної влади України, дипломатичними представництвами, міжнародними і громадськими (у т.ч. правозахисними) організаціями й іншими зацікавленими особами;

- щорічні моніторингові візити до всіх пунктів тримання за участі представників влади, дипломатичних представництв, міжнародних і неурядових організацій; 
Права людини в Україні та у зарубіжних країнах: традиції та новації

- щоквартальні письмові анонімні опитування серед затриманих мігрантів;

- функціонування гарячої лінії для отримання скарг.

3 початком збройного конфлікту в Україні не менш важливу роль щодо моніторингу забезпечення прав людини відіграє неурядова міжнародна організація Міжнародний Комітет Червоного Хреста.

Міжнародний комітет Червоного Хреста (далі - МКЧХ) $є$ незалежною гуманітарною організацією, яка спрямовує діяльність із забезпечення захисту жертв міжнародних i внутрішніх збройних конфліктів. Утворений у 1863 p. уродженцем Швейцарії Анрі Дюнаном, МКЧХ є засновником Руху Червоного Хреста, основне завдання якого - забезпечення дотримання воюючими сторонами положень Женевських конвенцій 1949 р. про захист жертв збройних конфліктів $i$ Додаткових протоколів до них.

Штаб-квартира знаходиться в Женеві, представництва Організації, в яких загалом працює понад 12 тис. осіб, розташовані в майже 80 країнах світу. Емблемою є червоний хрест на білому фоні. МКЧХ у діяльності слідує таким девізам «Inter arma caritas» («Милосердя на полі бою»), «Per humanitatem ad pacem» («Через гуманізм до миру») [33].

Метою Організації $\epsilon$ відстоювання та поширення основоположних принципів Руху Червоного Хреста (гуманність, нейтральність, неупередженість, універсальність тощо), виконання покладених Женевськими конвенціями завдань із забезпечення дотримання норм міжнародного гуманітарного права під час збройних конфліктів, забезпечення роботи Центральної агенції з розшуку, а також ведення роз'яснювальної роботи із застосування гуманітарного права під час збройних конфліктів серед причетних міністерств і відомств.

Відповідно до мандату, який надано МКЧХ світовою спільнотою, організація надає допомогу особам, що знаходяться під вартою, хворим, пораненим і цивільним особам, що постраждали в результаті збройного конфлікту, керуючись принципом неупередженості.

У ситуаціях збройного конфлікту МКЧХ координує діяльність національних товариств Червоного Хреста й Червоного Півмісяця та Міжнародної Федерації Товариств Червоного Хреста й Червоного Півмісяця. 
Під час збройних конфліктів міжнародного або внутрішнього характеру МКЧХ надає захист і допомогу жертвам як серед військовослужбовців, так і серед цивільного населення, зокрема військовополоненим, цивільним інтернованим особам, пораненим, цивільному населенню на окупованій території тощо.

Разом із реалізацією гуманітарних програм МКЧХ сприяє розвитку права збройних конфліктів 3 метою забезпечення ефективного захисту тих, хто не бере участі або припинив брати участь у військових діях.

Пріоритетами відносин нашої держави з МКЧХ залишається співробітництво Комітету 3 Національним Товариством Червоного Хреста України в допомозі особам, постраждалим унаслідок конфлікту на сході України. Нині Комітетом відкрито шість офісів у нашій державі - у Харкові, Донецьку, Луганську, Сєверодонецьку, Маріуполі й Одесі. Організація активно задіяна в мобілізації ресурсів для постраждалих регіонів. Зокрема, по лінії МКЧХ виділяється допомога українським родинам, переміщеним особам і лікарням у вигляді матеріалів для ремонту житла (скло, бетон, покрівельні матеріали), продуктів харчування, теплого одягу, медичних матеріалів, ліків тощо.

Національні товариства Червоного Хреста представлені 186 національними об'єднаннями, що визнані МКЧХ та $\epsilon$ повноправними членами федерації. Кожен із них працює у своїй країні відповідно до принципів міжнародного гуманітарного права та статутів руху. Залежно від обставин національні об'єднання можуть виконувати додаткові гуманітарні завдання, які безпосередньо не визначаються міжнародним законодавством чи мандатами членів міжнародного руху. Національні товариства виступають як помічники державної влади своїх країн у гуманітарній сфері та надають цілу низку послуг, які включають надання допомоги в надзвичайних ситуаціях, здійснення медичних і соціальних програм. Окрім того, під час війни вони допомагають цивільному населенню й у разі необхідності надають підтримку військово-медичній службі.

Указом Президента України «Про товариство Червоного Хреста України» від 28 жовтня 1992 р. це товариство визнане уповноваженим надавати допомогу особовому складу Збройних Сил України під час збройного конфлікту. Цей факт зробив можливим звернення Національного товариства до Міжнародного Комітету Червоного Хреста із заявкою при 
Права людини в Україні та у зарубіжних країнах: традиції та новації

визнання учасником Руху. Український Червоний Хрест став учасником Руху в 1993 р.

Крім Указу Президента, правовий статус Національного товариства Червоного Хреста на території нашої держави регулюються Законом України «Про Товариство Червоного Хреста України» від 28 листопада 2002 р. Цей Закон містить додаткові гарантії діяльності Товариства, передбачає його незалежність, забороняє органам державної влади втручатися в його діяльність тощо.

Відповідно до статті 1 указаного Закону, Товариство Червоного Хреста України (далі - Товариство) є всеукраїнською добровільною громадською гуманітарною організацією. Товариство допомагає державі в наданні медичної та гуманітарної допомоги під час збройних конфліктів і в мирний час, бере участь у наданні міжнародної допомоги в разі катастроф і надзвичайних ситуацій, забезпечує медико-соціальну допомогу найменш соціально захищеним верствам населення.

\section{Товариство в процесі діяльності:}

- здійснює збір різних видів гуманітарної допомоги від юридичних і фізичних осіб України, іноземних осіб, осіб без громадянства, міжнародних організацій для адресатів на території України;

- бере участь у розподілі гуманітарної допомоги, отриманої із зазначених вище джерел;

- здійснює діяльність, що випливає із Женевських конвенцій 3 питань надання допомоги пораненим, хворим та іншим особам, які постраждали під час збройних конфліктів;

- співпрацює із закладами охорони здоров'я України, епідеміологічною службою України, спеціалізованими підрозділами уповноваженого центрального органу виконавчої влади 3 питань надзвичайних ситуацій та у справах захисту населення від наслідків Чорнобильської катастрофи й медичною службою Збройних Сил України;

- співпрацює 3 державними органами з питань розміщення, транспортування, медичного та іншого обслуговування суб'єктів гуманітарної допомоги;

- отримує, реєструє, зберігає й надає інформацію про жертви стихійного лиха або збройних конфліктів;

- створює загони першої допомоги під час збройних конфліктів i стихійного лиха, здійснює пошук поранених i 
Права людини в Україні та у зарубіжних країнах: традиції та новації

загиблих унаслідок катастроф, стихійних лих, збройних конфліктів, установлює місця їх поховання, надає допомогу в цьому державним установам;

- сприяє органам державної влади й органам місцевого самоврядування в транспортуванні, прийнятті та розміщенні евакуйованого населення й біженців, наданні їм безоплатної медико-соціальної допомоги;

- організовує роботу служби розшуку Товариства та здійснює розшук осіб, які пропали безвісти, допомагає встановлювати зв'язки між членами сімей, роз'єднаних унаслідок збройних конфліктів чи виникнення надзвичайних ситуацій, сприяє возз'єднанню сімей, розшукує могили захисників Батьківщини, які загинули й поховані за межами України [34].

Національні товариства відіграють важливу роль у реалізації положень міжнародного гуманітарного права. Власне члени національних товариств Червоного Хреста, діючи безпосередньо на полі бою, надають допомогу хворим і пораненим воїнам, цивільному населенню, що загалом суттєво поліпшує захист жертв збройних конфліктів.

\section{Висновки}

Забезпечення прав i свобод громадян у правоохоронній діяльності має розглядатися як правова категорія, що відображає специфічну діяльність правоохоронних органів і їх посадових осіб зі створення умов, за яких реалізація прав і свобод громадян $\epsilon$ безперешкодною та максимально ефективною. Охорона прав і законних інтересів громадян здійснюється з метою запобігання найменшій можливості їх порушення, а захист сприяє їх відновленню та притягненню винної особи до відповідальності. Згідно зі змістом принципу верховенства права, ключовою функцією діяльності таких органів має стати не «управлінська», не «фіскальна» й тим більше не «каральна», а «правозабезпечувальна», яка пов'язана із забезпеченням реалізації прав, свобод і законних інтересів громадян.

Міжнародні стандарти у сфері забезпечення прав людини передбачені міжнародними договорами, конвенціями, деклараціями й іншими міжнародними документами, є системою міжнародних норм, принципів, правових та організаційних засобів, умов i вимог, за допомогою яких здійснюється дотримання, забезпечення, охорона й захист прав, свобод i 
Права людини в Україні та у зарубіжних країнах: традиції та новації

законних інтересів людини. Для ефективної діяльності із забезпечення прав громадян необхідно також прискорити процес адаптації законодавства України до стандартів Європейського Союзу, які гарантують повагу та дотримання таких прав у діяльності правоохоронних органів.

Щоб правоохоронець дотримувався й забезпечував реалізацію прав інших осіб, він має бути захищений сам у своїх правах і гарантіях. Усе ще гостро стоїть питання справедливої матеріальної компенсації за понаднормову працю, страхування ризиків для життя і здоров'я, забезпечення потреб повсякденної роботи. Гідна оплата праці й пенсійне забезпечення має мотивувати і стимулювати чесну працю. Держава повинна сприяти розвитку незалежних профспілок та об'єднань працівників поліції, які будуть відстоювати їхні права.

\section{Список використаних джерел:}

1. Про захист прав людини і основоположних свобод : Європейська конвенція від 04.11.1950. База даних «Законодавство України» / BP України. URL: https://zakon.rada.gov.ua/laws/show/995_004 (дата звернення: 07.04.2021).

2. Наливайко О.І. Функціональне призначення права у процесі захисту прав людини. Науковий вісник Юрид. акад. Міністерства внутр. справ. 2002. № 1. С. 57-64.

3. Губанов А.В. Полиция Запада: основы деятельности по охране правопорядка. Москва : ВНИИ МВД РФ, 1993. 158 с.

4. Загальна декларація прав людини. Права людини (основні міжнародно-правові документи) : збірник документів / упоряд. Ю.А. Качуренко. Київ : Наук. думка, 1989. 248 с.

5. Про громадянські і політичні права : Міжнародний пакт від 16.12.1966 № 995_043. База даних «Законодавство України» / BP України. URL: https://zakon.rada.gov.ua/laws/show/995_043 (дата звернення: 07.04.2021).

6. Про економічні, соціальні та культурні права : Міжнародний пакт від 19.10.1973. База даних «Законодавство України» / ВР України. URL: https://zakon.rada.gov.ua/laws/ show/995_042 (дата звернення: 07.04.2021).

7. Про Національну поліцію : Закон України від 02.07.2015 № 580-VIII. База даних «Законодавство України» / ВР України. 
Права людини в Україні та у зарубіжних країнах: традиції та новації

URL: https://zakon.rada.gov.ua /laws/show/580-19 (дата звернення: 07.04.2021).

8. Про Державну прикордонну службу : Закон України від 03.04.2003 № 661-IV. База даних «Законодавство Украӥни» / ВР України. URL: https://zakon.rada.gov.ua/laws/show/661-15 (дата звернення: 07.04.2021).

9. Про Службу безпеки України : Закон України від 25.03.1992 № 2229-XII. База даних «Законодавство України» / ВР України. URL: https://zakon.rada.gov.ua/laws/show (дата звернення: 07.04.2021).

10. Про затвердження Інструкції про порядок організації та проведення роботи 3 добору та вивчення кандидатів для проходження військової служби за контрактом особами рядового, сержантського і старшинського складу в Державній прикордонній службі України : Наказ Адміністрації Державної прикордонної служби України від 18 травня 2006 р. № 360. URL: https://ips.ligazakon.net/document/re12513 (дата звернення: 07.04.2021).

11. Про затвердження Інструкції 3 організації діяльності дільничних офіцерів поліції : Наказ МВС від 28.07.2017 № 650 База даних «Законодавство України» / BP України. URL: https://zakon.rada.gov.ua/laws/show/z1041-17 (дата звернення: 07.04.2021).

12. Стандарти забезпечення прав людини у діяльності Служби безпеки України : навчальний посібник / Д. фон Бларер, Ю.Л. Бєлоусов, С.С. Кудінов та ін. ; уклад. докт. екон. наук, проф. М.М. Чеховська ; за заг. ред. докт. юрид. наук, доц. С.С. Кудінова, канд. соц. наук Ю.Л. Бєлоусова. Київ : НА СБУ, 2019. 368 с.

13. Office of the High Commissioner for Human Rights (2001), Training Manual on Human Rights Monitoring. Professional Series No. 7. URL: https://www.ohchr.org/EN/PublicationsResources/ Pages/MethodologicalMaterials.aspx (дата звернення: 07.04.2021).

14. Про Офіс Омбудсмена в Україні. UNDP (2015), Проміжний огляд виконання Стратегії та Плану дій Офісу Омбудсмена (20132017). URL: https://www.ohchr.org/EN/PublicationsResources/ Pages/MethodologicalMaterials.aspx. (дата звернення: 07.04.2021).

15. Інструкція про порядок тримання затриманих осіб в органах (підрозділах) охорони державного кордону : Наказ МВС України від 30.03.2015 № 352. База даних «Законодавство 
Права людини в Україні та у зарубіжних країнах: традиції та новації

України» / ВР України. URL: https://zakon.rada.gov.ua/laws/show/ z0462-15 (дата звернення: 07.04.2021).

16. Положення про Управління моніторингу дотримання прав людини Міністерства внутрішніх справ України : Наказ МВС від 13.05.2017 № 386. URL: https://ips.ligazakon.net/document/ mvs726 (дата звернення: 07.04.2021).

17. Положення про Громадську раду при Міністерстві внутрішніх справ України : Наказ МВС України від 16.01.2020 № 38. URL: https://mvs.gov.ua/uk/for_citizens/polozennya-progromadsku-radu (дата звернення: 07.04.2021).

18. Про Уповноваженого Верховної Ради України з прав людини : Закон України від 27.12.1997 № 776/97-ВР. База даних «Законодавство України» / BP України. URL: https://zakon.rada.gov.ua/laws/show/776/97-вр (дата звернення: 09.04.2021).

19. Положення про Уповноваженого Президента України 3 прав дитини : Указ Президента України від 11.08.2011 № 811. База даних «Законодавство Украӥни» / ВP України. URL: https://zakon.rada.gov.ua /laws/show/811/2011 (дата звернення: 09.04.2021).

20. Про забезпечення функціонування української мови як державної : Закон України від 25.04.2019 № 2704-VIII. База даних «Законодавство України» / BP України. URL: https://zakon.rada.gov.ua/laws/show/2704-19 (дата звернення: 09.04.2021).

21. Про повноваження та гарантії здійснення постійного контролю за діяльністю Служби безпеки України : Указ Президента України від 18.05.2007 № 427/2007. База даних «Законодавство України» / BP України. URL: https://zakon.rada.gov.ua/laws/show/427/2007 (дата звернення: 09.04.2021).

22. Про зняття застережень України до Конвенції проти катувань та інших жорстоких, нелюдських або таких, що принижують гідність, видів поводження і покарання : Закон України від 05.11.1998. База даних «Законодавство України» / ВР України. URL: https://zakon.rada.gov. ua/laws/show/234-14 (дата звернення: 09.04.2021).

23. United Nations Ukraine. Розгляд доповідей, які представлені державами-учасниками відповідно до статті 19 Конвенції згідно факультативної процедури представлення 
Права людини в Україні та у зарубіжних країнах: традиції та новації

доповідей. Шоста періодична доповідь України, яка надана на розгляд у 2011 p. URL: http://www.un.org.ua/ua/informatsinyitsentr/news/3401-2014-11-07-23-13-41-komitet-oon-proti-katuvan$\operatorname{rozg}($ дата звернення: 09.04.2021).

24. Пропозиції УГСПЛ та партнерів враховано у Заключних зауваженнях Комітету ООН проти катувань щодо Періодичного звіту Російської Федерації. URL: https://helsinki.org.ua/articles/ propozytsiji-uhspl-ta-partneriv-vrahovano-u-zaklyuchnyhzauvazhennyah-komitetu-oon-proty-katuvan-schodo-periodychnohozvitu-rosijskoji-federatsiji (дата звернення: 09.04.2021).

25. Проти катувань та інших жорстоких, нелюдських або таких, що принижують гідність, видів поводження і покарання : Конвенція від 10.12.1984. База даних «Законодавство України» / BP України. URL: https://zakon.rada.gov.ua/laws/show/995_085 (дата звернення: 09.04.2021).

26. Проти катувань. Міжнародний механізм запобігання катувань та поганому поводженню / Харківська правозахисна група ; худож.-оформлювач Б.Є. Захаров. Харків : Права людини, 2007. $400 \mathrm{c}$.

27. Факультативний протокол до Конвенції проти катувань та інших жорстоких, нелюдських або таких, що принижують гідність, видів поводження та покарання від 21.07.2006. База даних «Законодавство України» / BP України. URL: https://zakon.rada.gov.ua/laws/show/995_f48 (дата звернення: 09.04.2021).

28. Права людини в Україні : Презентація доповіді Підкомітету $\mathrm{OOH}$ з недопущення катувань за підсумками візиту в Україну у 2016 році. URL: http://www.ukrinform.ua/rubricpresshall/2255132-prava-ludini-v-ukraini prezentacia-dopovidipidkomitetu-oon-z-nedopusenna-katuvan.html (дата звернення: 09.04.2021).

29. Ащенко О.М., Човган В.О. Українське пенітенціарне законодавство у світлі стандартів Комітетів проти катувань ООН та Ради Європи / передм. М.М. Гнатовского ; за заг. ред. Є.Ю. Захарова. Харків : Права людини, 2014. 332 с. URL: http://library.khpg.org/files/docs/ 1413663568.pdf (дата звернення: 12.04.2021).

30. Про запобігання катуванням чи нелюдському або такому, що принижує гідність, поводженню чи покаранню : Європейська конвенція від 26.11.1987. База даних «Законодавство Украӥни» / 
BP України. URL: https://zakon.rada.gov.ua/laws/show/995_068 (дата звернення: 12.04.2021).

31. Report to the Ukrainian Government on the visit to Ukraine carried out by the European Committee for the Prevention of Torture and Inhuman or Degrading Treatment or Punishment (CPT) from 8 to 21 December 2017. URL: https://rm.coe.int/16808d2c2a (дата звернення: 12.04.2021).

32. Права людини в сфері міжнародного захисту («притулку») - БФ «Право на захист». URL: https://helsinki.org.ua/prava-lyudyny-v-sferi-mizhnarodnohozahystu/\#_ftnref25 (дата звернення: 12.04.2021).

33. Статут Міжнародного комітету Червоного Хреста. База даних «Законодавство України» / BP України. URL: https://zakon.rada.gov.ua /laws/show/991_002 (дата звернення: 12.04.2021).

34. Про товариство Червоного Хреста : Закон України від 28.11.2008 № 330-IV. База даних «Законодавство України» / ВР України. URL: https://zakon.rada.gov.ua/laws/show/ 991_002?lang=uk (дата звернення: 12.04.2021). 